\title{
FIVE NEW SPECIES OF RECENT UNSTALKED CRINOIDS.
}

\author{
By Austin Нobart Clark,
}

Collaborator, Division of Marine Invertebrates, U. S. National Museum.

From time to time crinoids have been received at the U. S. National Museum which were evidently new species, but which have been left undescribed because of the absence of related species with which to make comparisons. One by one these missing species have come to hand and the relationships of previously obscure forms have been cleared up. In the present paper five species are described, the affinities of which have been brought out through the study of material recently received.

Family COMASTERIDA.

Genus COMANTHUS A. H. Clark.

Subgenus COMANTHUS A. H. Clark.

Group BENNETTIA A. H. Clark.

COMANTHUS (COMANTHUS) PINGUIS, new species.

Centro-dorsal large and hemispherical, with a concave polar area, as in $C$. $(C$.) bennetti, $10 \mathrm{~mm}$. to $12 \mathrm{~mm}$. in diameter.

Cirri large and stout as in $C$. $(C$.) bennetti, usually XXXV-XLV, $28-34,30 \mathrm{~mm}$. to $40 \mathrm{~mm}$. long, the joints in the proximal half squarish or slightly longer than broad, in the distal becoming about twice as broad as long; at about the twelfth the distal dorsal edge of the joints begins to project, and later the dorsal surface becomes carinate, so that in lateral view the cirri appear to have well-developed dorsal spines.

Division series all $4(3+4)$, IIBr and IIIBr regularly, IVBr rarely, present, very broad and massive, the IIBr series nearly in apposition laterally.

Usually thirty-five to forty arms $100 \mathrm{~mm}$. to $140 \mathrm{~mm}$. long, the brachials slightly overlapping. 
Disk very large, $30 \mathrm{~mm}$. to $42 \mathrm{~mm}$. in diameter, naked; anal tube large, central or subcentral; mouth variable, radial.

$P_{D}$ very stout basally but tapering rather rapidly as far as the ventral surface of the disk, $35 \mathrm{~mm}$. to $40 \mathrm{~mm}$. long; $\mathrm{P}_{\mathrm{P}}$ less stout basally, $30 \mathrm{~mm}$. long; $\mathrm{P}_{1} 25 \mathrm{~mm}$. long; $\mathrm{P}_{2}$ small, weak, and slender, $10 \mathrm{~mm}$. to $12 \mathrm{~mm}$. long; $\mathrm{P}_{3}$ and $\mathrm{P}_{4}$ similar, $7 \mathrm{~mm}$. and $6 \mathrm{~mm}$. long, respectively; $\mathrm{P}_{5}$ and following pinnules $5 \mathrm{~mm}$. long, without terminal combs, increasing slowly to $12 \mathrm{~mm}$. distally.

Type-specimen.-Cat. No. 25517, U.S.N.M., from Sagami Bay, Japan.

This is the most common comasterid along the shores of southern Japan, where it appears to represent $C$. $(C$.$) bennetti of the East$ Indian littoral. It may be at once distinguished from that species by the great breadth of the division series, the short distal civrus joints, which bear dorsal processes, and the much smaller number of arms. Carpenter's Actinometra robustipinna appears to be a synonym of Müller's Alecto bennetti.

COMANTHUS (COMANTHUS) SAMOANA, new species.

Centro-dorsal small, discoidal, the bare polar area flat, $2 \mathrm{~mm}$. or $3 \mathrm{~mm}$. in diameter; cirrus sockets arranged in a single more or less irregular marginal row.

Cirri short, but comparatively stout XVIII-XXIII, usually 13-14, $10 \mathrm{~mm}$. long; fourth and fifth joints about twice as long as broad, the seventh and following about one-third broader than long; fifth and following joints with the distal dorsal edge somewhat thickened, this thickening gradually narrowing distally and increasing in height, appearing in lateral view as a slight subterminal tubercle; third, fourth, and fifth joints " dice-box shaped" with enlarged ends, the following rather strongly flattened laterally so that in lateral view the cirri appear to increase in diameter distally.

Radials and usually all of the $\mathrm{IBr}_{1}$ concealed; $\operatorname{IIBr} 4(3+4)$ well separated laterally.

Fifteen to twenty-one arms $60 \mathrm{~mm}$. to $70 \mathrm{~mm}$. long, rather slender, resembling those of $C$. $(C$. ) trichoptera, the brachials in the proximal half with rather strongly overlapping distal edges.

Pinnules essentially as in $C$. $(C$.) trichoptera, but remarkable for the great development of spines on the dorsal surface of the joints.

Type-specimen.-Cat. No. 25514, U.S.N.M., from Samoa; collected by C. N. E. Eliot.

The stout and numerous cirri of this little species render it very readily distinguishable from $C$. $(C$.) rotalaria, while the slender and thread-like cirri of $C(C$.$) trichoptera at once differentiate that$ species from it. 


\section{Family HIMEROMETRID无.}

\section{Genus CRASPEDOMETRA A. H. Clark.}

CRASPEDOMETRA ALIENA, new species.

Centro-dorsal thick-discoidal, the bare polar area flat, $2 \mathrm{~mm}$. to $4 \mathrm{~mm}$. in diameter; cirrus sockets arranged in a single or partially double alternating marginal row.

Cirri XV-XVII, 29-36 (usually 35 or 36 ), $30 \mathrm{~mm}$. long, moderately stout basally, but tapering very gradually to a slender tip; first joint short, the following gradually increasing in length to the fourth or fifth, which is squarish, the remainder being slightly longer than broad; the terminal ten to fourteen may have a slight dorsal carination; opposing spine small but prominent, terminal or subterminal. about equal to one-third the diameter of the penultimate joint in height; terminal claw somewhat longer than the penultimate joint, slender and slightly curved; joints in the distal half or two-thirds of the cirri with purple saddle-shaped markings, as in $C$. acuticirra.

Radials entirely concealed in the median line, or equal to half the $\mathrm{IBr}_{1}$ in length; $\mathrm{IBr}_{1}$ oblong, short, five or six times as broad as long, united laterally; $\mathrm{IBr}_{2}$ (axillary) short, almost or quite triangular, two and one-half to three times as broad as long; IIBr4 $(3+4)$ (twice 2 in one specimen) in apposition and flattened laterally; IIIBr2, but only once present in two specimens, developed internally.

Fifteen to twenty arms, $140 \mathrm{~mm}$. long, long, slender, and evenly tapering; first two brachials subequal, slightly wedge-shaped, between three and four times as broad as long in the median line; third and fourth brachials (syzygial pair) oblong, two and one-half or three times as broad as long; next five brachials approximately oblong, nearly four times as broad as long in the median line; following brachials triangular, somewhat over twice as broad as long, the longer side somewhat convex, after the proximal fourth of the arm becoming wedge-shaped, about three times as broad as long, and slightly longer terminally. Syzygies occur between the third and fourth brachials, again between the fourteenth and fifteenth to twenty-ninth and thirtieth, and distally at intervals of from eleven to nineteen oblique muscular articulations.

$\mathrm{P}_{\mathrm{D}}$ small and weak, about $6 \mathrm{~mm}$. long, with thirteen to sixteen joints, all of which are about as long as broad; $\mathrm{P}_{1}$ similar, slightly larger, $7 \mathrm{~mm}$. or $8 \mathrm{~mm}$. long; $\mathrm{P}_{2} 9 \mathrm{~mm}$. to $12 \mathrm{~mm}$. long, with eighteen joints, much stouter and stiffer than the preceding pinnules, ending somewhat abruptly with a stiffened tip, as in Stephanometra, and not a long delicate flagellate tip, as in the other species of the genus; first two joints not so long as broad, the third squarish, the remainder longer than broad, becoming twice as long as broad distally; the pin- 
nule may be slightly carinate basally, and after the second or third joint the distal dorsal ends of the joints become thickened and project strongly, forming "lateral processes," as in Amphimetra variipinna; $\mathrm{P}_{3}$ slightly stouter and slightly longer than $\mathrm{P}_{2}$, usually with a few less joints, but similar to it; $\mathrm{P}_{4} 9 \mathrm{~mm}$. long, comparatively slender, without lateral processes; the joints becoming squarish on the fourth or fifth and about twice as long as broad terminally; following similar, gradually increasing to $10 \mathrm{~mm}$. in length and then becoming more slender and slowly decreasing to $8 \mathrm{~mm}$. in length.

Color (in spirits).-White, the cirrus joints with purple saddleshaped markings in the distal half or two-thirds of the cirri.

Type-specimen.-Cat. No. 25516, U.S.N.M., from Albatross station 5157, west of Sunalac Island (Tataan group, Philippine Archipelago); 18 fathoms.

\section{Genus AMPHIMETRA A. H. Clark.}

AMPHIMETRA PARILIS, new species.

Centro-dorsal thick-discoidal, the bare polar area flat, $2.5 \mathrm{~mm}$. in diameter; cirrus sockets arranged in one and a partial second crowded marginal row.

Cirri XII, 30-33, 25 to $30 \mathrm{~mm}$. long, moderately stout; joints subequal, all broader than long, at first very short, then slowly increasing to the seventh or eighth, which, with the three or four following; is about half again as broad as long, then very slowly decreasing, so that the joints in the distal half of the cirri are about twice as broad as long; twelfth and following joints with prominent median dorsal spines, which are directed anteriorly; opposing spine longer than the spines on the preceding joints, sharp, triangular, rather slender, the apex median, rising to a height about equal to half the diameter of the penultimate joint; terminal claw longer than the penultimate joint, slender, more strongly curved proximally than distally.

Radials just visible in the median line, forming a low triangle in the angles of the calyx, the lateral corners slightly swollen; $\mathrm{IBr}_{1}$ oblong, four times as broad as long, almost entirely united laterally; $\mathrm{IBr}_{2}$ (axillary) almost or quite triangular, somewhat over twice as broad as long, in apposition and laterally flattened.

Ten arms $150 \mathrm{~mm}$. long, tapering rather less rapidly than in $\mathrm{A}$. discoidea and A. formosa; first two brachials short, wedge-shaped, the second slightly the longer exteriorly, but tapering almost to a point interiorly, the first entirely united interiorly ; third and fourth brachials (syzygial pair) oblong, two and one-half or three times as broad as long; next seven or eight brachials oblong, very short, about four times as broad as long or even shorter, then becoming wedge-shaped, about the same length, and in the distal half of the arm oblong and very short. In the proximal third of the arm the proximal edge of 
the brachials is somewhat raised, but the remainder of the arm is perfectly smooth. Syzygies occur between the third and fourth brachials, again between the ninth and tenth or fourteenth and fifteenth (if the former, another occurs between the fourteenth and fifteenth or fifteenth and sixteenth), and thence at intervals of from seven to seventeen oblique muscular articulations up to about the middle of the arm, beyond which point syzygies are rare or entirely lacking.

$P_{1} 9 \mathrm{~mm}$. long with thirty joints, broad basally but tapering rapidly and slender and flagellate in its outer half; first eight joints broader than long, very considerably so at first, the remainder squarish; $\mathrm{P}_{2} 13 \mathrm{~mm}$. long with thirty joints, stout like $\mathrm{P}_{1}$ in its basal third but tapering rapidly and slender and flagellate distally; first six joints broader than long, the remainder squarish; the broad lower joints, as in $\mathrm{P}_{1}$, are carinate; $\mathrm{P}_{3} 19 \mathrm{~mm}$. long, much stouter than $\mathrm{P}_{1}$ or $\mathrm{P}_{2}$, but of the same general shape, stout basally, becoming gradually slender distally with a flagellate tip, with thirty joints; $\mathrm{P}_{4} 20$ mm. long, stouter and stiffer than $\mathrm{P}_{3}$, with about twenty-five joints, the first ten broader than long, the following squarish, becoming slightly longer than broad distally; like $\mathrm{P}_{3}, \mathrm{P}_{4}$ is carinate in its basal half and has a low lateral keel in its outer two-thirds; $\mathrm{P}_{5} 10 \mathrm{~mm}$. long, about as stout basally as $\mathrm{P}_{2}$, but not tapering so rapidly, with seventeen joints, the first six longer than broad, the remainder squarish; first seven joints strongly carinate; $\mathrm{P}_{6}$ and following pinnules 7 $\mathrm{mm}$. long with sixteen joints, slender, about as stout as $P_{1}$ proximally, but not tapering so rapidly, the first five or six joints broader than long and strongly carinate, then squarish, and finally slightly longer than broad; distal pinnules $10 \mathrm{~mm}$. long, moderately slender; the carination of the lower pinnule joints gradually dies away at the end of the proximal fourth of the arm.

Color (in spirits).-Greenish yellow, the cirri purple in the outer two-thirds; disk mottled green and brown; brachial and pinnule perisome light blue.

Type-specimen.-Cat. No. 25515, U.S.N.M., from Albatross station 5147; off Balinpongpong Island (south of Jolo), Philippines; 21 fathoms.

\section{Family TROPIOMETRIDA.}

\section{Genus PTILOMETRA A. H. Clark.}

PTILOMETRA SPLENDIDA, new species.

Centro-dorsal columnar, $4 \mathrm{~mm}$. long and $3 \mathrm{~mm}$. in diameter, the center of the dorsal pole concave and surrounded by five broad low tubercles radially situated; cirrus sockets arranged in ten evenly spaced columns, usually three to a column.

Proc. N. M. vol. $37-09-3$ 
Cirri XXX, 86, $50 \mathrm{~mm}$. long, very long and slender, slightly tapering distally; first joint short, second twice as broad as long, the following gradually increasing in length to the fifth or sixth, which is squarish, and still further increasing to the thirteenth or seventeenth, which is about half again as broad as long, or sometimes slightly longer, after the nineteenth to twenty-sixth decreasing rather rapidly in length, soon becoming twice as broad as long, and even shorter terminally; joints from about the seventh or eighth to twenty-fifth with the median portion of the ventral edge produced into a long slender curved overlapping spine, as in $P$. trichopoda, this reaching a maximum size on the tenth to the thirteenth joints and then gradually dying away distally; as the ventral spines on the cirrus joints die away, a slight prominence begins to appear on the distal edge in the median line which gradually becomes a prominent tubercle, and encroaches more and more upon the dorsal surface of the joints, becoming the broad, high, curved, carinate dorsal spine characteristic of the terminal joints of the cirri in all the species of this genus.

Ends of the basal rays visible as small dorso-ventrally elongate tubercles in the angles of the calyx; radials short, of equal height all around the calyx, four or five times as broad as long, with a trace of a broad median tubercle; $\mathrm{IBr}_{1}$ oblong, four times as broad as long, laterally united in the basal half; $\mathrm{IBr}_{2}$ (axillary) very broadly pentagonal, two and one-half times as broad as long, with a slightly produced lateral border, and, like the $\mathrm{IBr}_{1}$, faintly carinate; IIBr2; IIIBr2, developed exteriorly; division series externally with slightly produced ventro-lateral edges.

Thirty arms, $80 \mathrm{~mm}$. long, resembling in general those of $P$. trichopoda, but somewhat more compressed and deeper proximally, and sharply rounded instead of carinate distally.

Pinnules essentially as in $P$. trichopoda, but slightly stouter.

In general shape this species is unique in the genus, resembling such species of Pachylometra as $P$. angusticalyx; very narrow at the radials and $\mathrm{IBr}_{1}(5 \mathrm{~mm}$.), the width increases rather rapidly to about the seventh brachial $(20 \mathrm{~mm}$.), giving the dorsal part of the animal the appearance of being strongly constricted and disproportionately small.

Type-specimen.-Cat. No. 25518, U.S.N.M., from Albatross station 5179; between Tablas and Romblon, Philippine Islands; 37 fathoms. 


\section{$2 \mathrm{BHL}$ Biodiversity Heritage Library}

Clark, Austin Hobart. 1909. "Five new species of Recent unstalked crinoids." Proceedings of the United States National Museum 37(1697), 29-34.

https://doi.org/10.5479/si.00963801.37-1697.29.

View This Item Online: https://www.biodiversitylibrary.org/item/53183

DOI: https://doi.org/10.5479/si.00963801.37-1697.29

Permalink: https://www.biodiversitylibrary.org/partpdf/51124

\section{Holding Institution}

Smithsonian Libraries

\section{Sponsored by}

Smithsonian

\section{Copyright \& Reuse}

Copyright Status: NOT_IN_COPYRIGHT

This document was created from content at the Biodiversity Heritage Library, the world's largest open access digital library for biodiversity literature and archives. Visit BHL at https://www.biodiversitylibrary.org. 